\title{
Cytotoxic effect of extract from Dunaliella salina against SH-SY5Y neuroblastoma cells
}

\author{
Belkis Atasever-Arslan ${ }^{1}$, Kaan Yilancioglu ${ }^{2}$, Maide G. Bekaroglu ${ }^{1,3}$, Emre Taskin ${ }^{4}$, Eyup Altinoz ${ }^{5}$ \\ and Selim Cetiner ${ }^{6}$ \\ ${ }^{1}$ Department of Molecular Biology and Genetics, Faculty of Engineering and Natural Sciences, Üsküdar University, Istanbul, \\ Turkey \\ ${ }^{2}$ Department of Biomedical Equipment Technology, Üsküdar University, Istanbul, Turkey \\ ${ }^{3}$ Physics Engineering Department, Faculty of Science and Letters, Istanbul Technical University, Istanbul, Turkey \\ ${ }^{4}$ Department of Medical Biology, Faculty of Medicine, Karabuk University, Karabuk, Turkey \\ ${ }^{5}$ Department of Biochemistry, Karabuk University, Karabuk, Turkey \\ ${ }^{6}$ Biological Sciences and Bioengineering Program, Faculty of Engineering and Natural Sciences, Sabanci University, Istan- \\ bul, Turkey
}

\begin{abstract}
Cytotoxic effects of essential oils extracted from Dunaliella salina on SH-SY5Y human neuroblastoma cells were investigated in this study. GC-MS analysis was used for determination of the composition of essential oils found in Dunaliella salina extract. All experimented concentrations of Dunaliella salina extract on SH-SY5Y human neuroblastoma cells were significantly more cytotoxic than the tested concentrations of the extract on ECV304 human endothelial cells used as a control. Fifthy compounds were detected in GC-MS analysis of the extract, and five major compounds were predominantly found as follows: octadecanoic acid, methyl ester (27.43\%); hexadecanoic acid, methyl ester (Cas) methyl palmitate (24.82\%); 9,12,15-octadecatrienoic acid, ethyl ester, (Z,Z,Z)- (7.39\%); octadecanoic acid (5.03\%), pentadecanoic acid (3.60\%). The cytotoxic activity of Dunaliella salina extract on SH-SY5Y human neuroblastoma cells might be due to high concentrations of octadecanoic acid and hexadecanoic acid. Furthermore, results indicate that the extract demonstrates some proliferative effect on ECV304 cells in a dose-dependent manner between 0.25 and $5 \mu \mathrm{g} / \mathrm{ml}$. These results suggest that Dunaliella salina may have anticancer potential against human neuroblastoma cells.
\end{abstract}

Key words: Algae - Cytotoxicity - Dunaliella salina - Essential oil - SH-SY5Y human neuroblastoma cells

\section{Introduction}

Neuroblastoma is a tumor that appears in childhood with high incidence and mortality rate. It is one of the most common malignant tumors of infants, besides being responsible for the majority of pediatric cancers (Gonzalez-Nunez et al. 2014). Neuroprotective effects of various anticancer compounds such as wheat germ peptide, arctigenin have been reported previously (Cheng et al. 2014; Li et al. 2014).

Correspondence to: Belkis Atasever-Arslan, Department of Molecular Biology and Genetics, Faculty of Engineering and Natural Sciences, Üsküdar University, Istanbul, Turkey

E-mail: belkisatasever.arslan@uskudar.edu.tr
Protective, antioxidant, antimutagenic, antitumoral, antiinflammatory, anticoagulant and antiviral activities of various algae have been also reported (Kotake-Nara et al. 2005; Miadoková et al. 2005; Ishikawa et al. 2008; Gamal-Eldeen et al. 2009; Miadoková et al. 2010; Zandi et al. 2010; Bechelli et al. 2011; Machana et al. 2012). However, drug potentials of algae species against neuroblastoma cells are being investigated, the information about the anticancer and/or selective cytotoxic effects of algae compounds on neuroblastoma cells is limited.

Dunaliella salina (Chlorophyta, Chlorophyceae) is a unicellular wall-less biflagellate green alga. It has been shown that the potential of biotechnological use of Chlorophyceae family members is becoming more important especially 
in the field of sustainable and recyclable, clean energy production ( $\mathrm{Li}$ et al. 2011). For this reason, large-scale production processes have been successfully optimized in both open and closed production systems, particularly for Dunaliella, Spirullina, Chlorella, Scenedesmus algae species (Rastogi and Incharoensakdi 2013; Zemke et al. 2013; Fu et al. 2014).Therefore, it is hypothesized that the production of potential drug molecules from algae species via using already well-optimized large-scale production systems is highly possible.

In this study, Dunaliella salina green algae is assessed for its anticancer drug potential for targeting malignant neuroblastoma cells. Cytotoxicity assay was applied to SHSY5Y neuroblastoma cells and examined in comparison with ECV304 as the control. The composition of essential oils obtained from Dunaliella salina extract was characterized by using gas chromatography-mass spectrometry (GC-MS) analysis.

\section{Materials and Methods}

\section{Mammalian cell cultures}

SH-SY5Y cells were subjected to analyze cytotoxic potential of Dunaliella salina extract. ECV304 human umbilical vein endothelial cell line was used as a control. Because ECV304 cell line presents many features of endothelial cells (Suda et al. 2001), we used it as a non-cancerous cellular model. Both cell lines were purchased from American Type Culture Collection (ATTC).

DMEM medium (HyClone, 16777-133) supplemented with $10 \%$ fetal bovine serum (HyClone, SH3007003HI), 1\% penicillin-streptomycin, $1 \% \mathrm{~L}$-glutamine solution and $0.1 \%$ MEM non essential amino acids solution (100 $\times$ ) were used in cell culture experiments and all incubations were performed in a humidified atmosphere containing $5 \% \mathrm{CO}_{2}$ at $37^{\circ} \mathrm{C}$. 96 well plate, polystyrene cell culture flasks (Greiner Inc.) were used for viability assays and cell cultures, respectively. For experimental procedure, SH-SY5Y and ECV304 cells were detached by $0.5 \%$ Trypsin-EDTA solution (Sigma, T3924), washed with PBS twice and resuspended in DMEM at $5 \times$ $10^{5}$ cells/ml density.

\section{Cytotoxicity assay}

The cytotoxic effects of Dunaliella salina extract on SH-SY5Y human neuroblastoma and on ECV304 human endothelial cells were measured via MTT (3-(4,5-dimethylthiazol-2yl)2,5-diphenyl tetrazolium bromide) (Sigma, M-5655) assay (Atasever et al. 2010; Pirildar et al. 2010; Svobodova et al. 2012). Cells were suspended at $1 \times 10^{6}$ cells $/ \mathrm{ml}$ in DMEM medium supplemented with $10 \%$ fetal bovine serum, $1 \%$ penicillin-streptomycin, $1 \% \mathrm{~L}$-glutamine solution and $0.1 \%$ MEM non essential amino acids solution $(100 \times)$ at $37^{\circ} \mathrm{C}$ in a humidified atmosphere containing $5 \% \mathrm{CO}_{2}$.

Stock solutions of the Dunaliella salina extract were prepared in dimethylsulfoxide (DMSO; Sigma D 5879), $10 \mathrm{mg} / \mathrm{ml}$. The following final aqueous concentrations were prepared by serial dilutions of the stock solution: 4000,500 , $50,5,2.5 \mu \mathrm{g} / \mathrm{ml}$. This suspension $(90 \mu \mathrm{l})$ of the cells was then dispensed into 96-well round-bottom plates containing $10 \mu \mathrm{l}$ of the dilutions of the algae extracts. Thus, final concentrations of compounds were 400, 50, 5, 0.5, $0.25 \mu \mathrm{g} / \mathrm{ml}$, respectively. Medium $(10 \mu \mathrm{l})$ instead of algae extract was used as a positive control, and medium without cells and the extract was solely used as negative controls for optical density (OD) measurements. After 48 hours of incubation, $10 \mu$ freshly prepared MTT $(5 \mathrm{mg} / \mathrm{ml})$ solution in phosphate buffer saline (PBS) was added to each well and the plates were incubated $3 \mathrm{~h}$ at $37^{\circ} \mathrm{C}$. Then the supernatants were removed from all wells and $100 \mu \mathrm{l}$ of sodium dodecyl sulfate (SDS, pH 5.5) containing isopropyl alcohol was added to the wells in order to dissolve the formazan crystals formed by reduction of MTT in living cells. Then microplates were left in the dark room overnight. Optical density of each well was measured with $570 \mathrm{~nm}$ test wavelenght and a $655 \mathrm{~nm}$ reference wavelenght on an Bio-Rad Benchmark Microplate Reader (Philadelphia, USA). Cytotoxic index (CI) was calculated with the formula:

Cytotoxic index $=1-[\mathrm{OD}$ (treated wells) / OD (control wells) $\times 100 \%$

The cytotoxicity assay was repeated six times for each concentration of the extracts.

\section{Algae culture and extraction protocols}

Dunaliella salina (UTEX Collection No: LB1644, Texas, USA) was grown in $2 \times$ Erdschreiber's medium. The medium contained 3 liters of filtered and pasteurized supplemented seawater, P-IV metal solution ( $36 \mathrm{ml} / 3 \mathrm{l}), \mathrm{NaNO}_{3} 10 \mathrm{ml} / 3 \mathrm{l}$, $\mathrm{Na}_{2} \mathrm{HPO}_{4} \times 7 \mathrm{H}_{2} \mathrm{O}(10 \mathrm{ml} / 3 \mathrm{l})$, autoclaved and filtered soilwater: GR+ medium $(150 \mathrm{ml} / 3 \mathrm{l})$, vitamin $\mathrm{B} 12(3 \mathrm{ml} / 3 \mathrm{l})$. Instructions for preparing the culture medium is retrieved from the University of Texas at Austin (UTEX) culture collection of algae (http://www.sbs.utexas.edu/utex/mediaDetail. aspx?mediaID=166). Dunaliella salina was first extracted using pure methanol. The obtained methanol extract were evaporated by a rotavapor. The methanol extract was further dissolved in DMSO using an ultrasonic bath, and filtered just before the cytotoxicity assays.

\section{Gas chromatography-mass spectrometry (GC-MS) analysis}

Essential oils were analyzed using a Shimadzu gas chromatograph (QP5050, NY, USA), equipped with a Rtx ${ }^{\otimes}-5 \mathrm{MS}$ column ( $30 \mathrm{~m} \times 0.25 \mathrm{~mm}$ ID, $0.10 \mu \mathrm{m}$ film thickness). Nitrogen 
was used as a carrier gas (average flow rate, $1 \mathrm{ml} / \mathrm{min}$ ). Oven temperature program was as follows: $110^{\circ} \mathrm{C}(2 \mathrm{~min})$ to $200^{\circ} \mathrm{C}$ $\left(10^{\circ} \mathrm{C} / \mathrm{min}\right)$, then to $300^{\circ} \mathrm{C}\left(5^{\circ} \mathrm{C} / \mathrm{min}\right)$, post run $(9 \mathrm{~min})$ at $300^{\circ} \mathrm{C}$. Injector and detector (FID, Quadrupole(MS)) temperature was $250^{\circ} \mathrm{C}$ and $280^{\circ} \mathrm{C}$, respectively. The MS working in electron impact mode at $70 \mathrm{eV}$; ion source temperature $200^{\circ} \mathrm{C}$; mass spectra data were acquired in the scan mode in $\mathrm{m} / \mathrm{z}$ range $45-450$ (Paul et al. 2006).

\section{Identification of components}

Oil constituents were identified by using National Institute Standard and Technology (NIST) library (http://www.nist. gov/srd/nistla.cfm). Component relative percentages were calculated based on GC peak areas without using correction factors.

\section{Statistical analysis}

Statistical analysis was performed using Statistical Package for the Social Sciences (SPSS) software. Results were expressed as the mean \pm standard deviation (SD). Statistical differences were assessed by Student's unpaired $t$-test, with $p<0.05$ as statistically significant.

\section{Results}

SH-SY5Y human neuroblastoma cells were used to assess cytotoxic effects of Dunaliella salina, and ECV304 human endothelial cells were used as a control. SH-SY5Y and ECV304 cells were incubated with different concentrations (400, 50, $5,0.5,0.25 \mu \mathrm{g} / \mathrm{ml}$ ) of Dunaliella salina extract. The cytotoxic effect of Dunaliella salina extract on SH-SY5Y human neuroblastoma and on ECV304 human endothelial cells were measured by using MTT colorimetric assay. Figure 1 shows the cytotoxic activity of the Dunaliella salina extract against SH-SY5Y human neuroblastoma and ECV304 human endothelial cells. A significant cytotoxic effect of Dunaliella salina extract against SH-SY5Y human neuroblastoma cell was demonstrated at all concentrations besides there is not any significant effect on ECV304 human endothelial cells $(p<0.05)$. At the concentration level of $400 \mu \mathrm{g} / \mathrm{ml}$, Dunaliella salina extract showed about $43 \%$ of cytotoxic activity against SH-SY5Y cells, whereas $50 \mu \mathrm{g} / \mathrm{ml}$ concentation of the extract was lower (34\% of cytotoxicity) (Table 1). Cytotoxicity assays imply that the Dunaliella salina extract are cytotoxic for SH-SY5Y human neuroblastoma cells in a dose-dependent manner, but not for ECV304 cells. Especially, the extract has clearly different effects on malignant neuroblastoma and non-cancerous cells in a dose-dependent manner. The same dose $(400 \mu \mathrm{g} / \mathrm{ml})$ of Dunaliella salina extract showed minimal toxicity for non-cancerous endothelial cell line

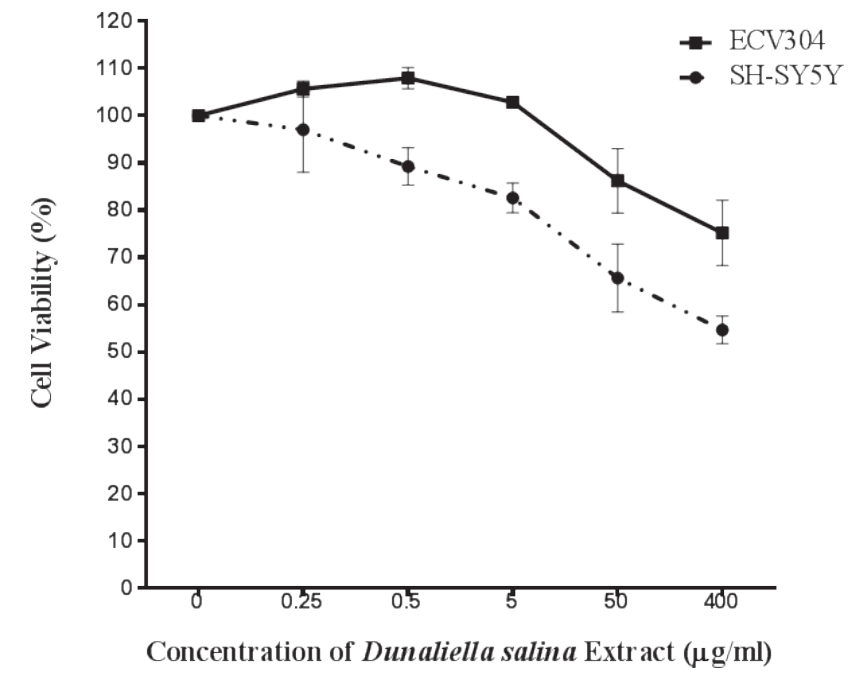

Figure 1. The cytotoxic activity of the Dunaliella salina extract against SH-SY5Y human neuroblastoma cells and ECV304 human endothelial cells. The cytotoxicity assay was repeated six times for each concentration of the extracts. It was found the significant cytotoxic effect of Dunaliella salina extract against SH-SY5Y human neuroblastoma cell $(p<0.05)$.

ECV304. This result indicates that one or a few chemical constituents of Dunaliella salina extract has/have highly selective cytotoxic effects on SH-SY5Y cells. With this cytotoxic properties, the chemical constituents of Dunaliella salina extract may have anti-cancer drug potential against SH-SY5Y human neuroblastoma cells.

Furthermore, results indicate that the extract may have some proliferative effect on ECV304 cells in a dosedependent manner between 0.25 and $5 \mu \mathrm{g} / \mathrm{ml}$. Considering the endothelial tissue damage contributed to pathogenesis of some diseases which have high morbidity and mortality

Table 1. Cytotoxicity index (CI) of Dunaliella salina extract on SH-SY5Y and ECV304 cell lines

\begin{tabular}{lcc}
\hline Cell line & $\begin{array}{c}\text { D. salina extract } \\
(\mu / \mathrm{ml})\end{array}$ & $\begin{array}{c}\text { CI } \\
(\%)\end{array}$ \\
\hline & 400 & $43.3 \pm 5.08$ \\
SH-SY5Y & 50 & $34.36 \pm 12.46$ \\
& 5 & $17.43 \pm 5.47$ \\
& 0.5 & $10.73 \pm 6.87$ \\
& 0.25 & $2.99 \pm 15.64$ \\
\hline & 400 & $24.83 \pm 6.91$ \\
ECV304 & 50 & $13.79 \pm 6.80$ \\
& 5 & $-2.82 \pm 0.22$ \\
& 0.5 & $-7.95 \pm 2.23$ \\
\hline
\end{tabular}


<smiles>CCCCCCCCCCCCCCCC(=O)OC</smiles>

Hexadecanoic acid, methyl ester (CAS) Methyl palmitate<smiles>CCCCCCCCCCCCCCCCCC(=O)O</smiles>

Octadecanoic acid<smiles>CCCCCCCCCCCCCCCCCC(=O)OC</smiles>

Octadecanoic acid, methyl ester<smiles>CCCCCCCCCCCCCCC(=O)O</smiles>

Pentadecanoic acid

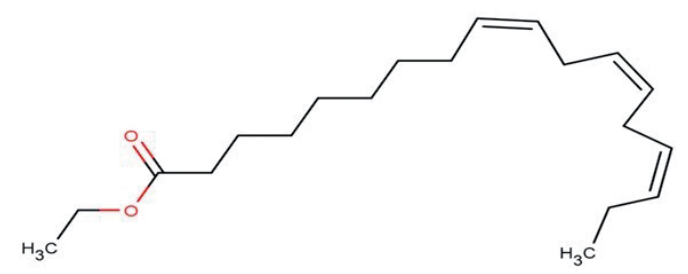

\section{9, 12, 15- Octadecanoic acid, ethyl ester, (Z,Z,Z)-}

Figure 2. Chemical structures of the major compounds found in the analyzed essential oils.

rate, as diabetic micro-vasculopathies, atherosclerosis and hypertension, this proliferating effect on ECV304 cells might be as important as the cytotoxic effect to SH-SY5Y cells.

GC-MS analysis allowed determining the composition of the essential oils of Dunaliella salina extract. Table 2 shows percentage composition of essential oils of the extract. A total of 50 compounds were identified in the extract. Five major compounds were identified as follows: octadecanoic acid, methyl ester (27.43\%), hexadecanoic acid, methyl ester (Cas) methyl palmitate (24.82\%), 9,12,15-octadecatrienoic acid, ethyl ester, (Z,Z,Z)- (7.39\%), octadecanoic acid (5.03\%), pentadecanoic acid (3.60\%). Figure 2 shows the chemical structures of the major compounds found in algae extracts. The following compounds were detected in also significant amounts (above 1\%): acetic acid, [(phenylmethoxy) imino]-, trimethylsilyl ester (3.08\%), hexadecanoic acid, 2-hydroxy-1-(hydroxymethyl) ethyl ester (2.11\%), phytol
(1.81\%), methyl eicosa-5,8,11,14,17-pentaenoate (1.79\%), 9,12-octadecadienoic acid (Z,Z)- (1.62\%), N-methyl-N(methyl-D3) aminoheptane (1.62\%), oxiranemethanol (Cas) glycidol (1.57\%), hexanoic acid, heptadecyl ester (1.57\%). These results demonstrate that extraction of Dunaliella salina generates various fatty acids which may have a cytotoxic effects on neuroblastoma cells.

Also the minor compounds were identified (under 1\%, see Table 2).

\section{Discussion}

Neuroblastoma is one of the most common childhood neoplasms originating from neural crest progenitor cells of the sympathetic nervous system ( $\mathrm{Gu}$ et al. 2014). In our study, SH-SY5Y human neuroblastoma cells were used to assess cytotoxic effects of Dunaliella salina extract.

The protective effects of Dunaliella salina against fibrosarcoma cells were already reported (Raja et al. 2007). As far as we know, there is not any published report describing antitumoral effects of Dunaliella salina against neuroblastoma cells yet. We first demonstrated the cytotoxic effects of Dunaliella salina extracts on malignant neuroblastoma cells in this study.

Five major compounds of Dunaliella salina were identified as octadecanoic acid, methyl ester (27.43\%), hexadecanoic acid, methyl ester (Cas) methyl palmitate (24.82\%), 9,12,15-octadecatrienoic acid, ethyl ester, (Z,Z,Z)-(7.39\%), octadecanoic acid (5.03\%), pentadecanoic acid (3.60\%). Palmitic acid, or in other words hexadecanoic acid, is the most common fatty acid (saturated) found in animals, plants and microorganisms (Fattore and Fanelli 2013), and proven similarly on neuroblastoma cells. Pareira and colleagues previously showed the apoptotic effect of palmitic acid from Marthasterias glacialis L. extract against SH-SY5Y cells. The major compound of Dunaliella salina extract is also palmitic acid (Pereira et al. 2013).

Octadecanoic acid detected as one the major compounds found in extracts of the algae is a saturated fatty acid with an 18-carbon chain and also defined as stearic acid. On the other hand, Hagen and colleagues found that octadecanoic acid (steraic acid) has proliferative effects on prostatic cancer cells (Hagen et al. 2013). These results imply to be a antagonistic relationship between palmitic acid and octadecanoic acid. Only palmitic acid is shown to cause more cytotoxicity against SH-SY5Y cells. In another study it was shown that steraic acid stimulated Akt-dependent activation of NF- $\kappa B$ (Subbaramaiah et al. 2013). However, Khan and colleagues demonstrated that steraic acid, as an ester derivative, inhibits the growth of human breast cancer cells (Khan et al. 2013). Cytotoxicicity of steraic acid might show differences depending on the properties of cancerous cells. Therefore synergistic 
Table 2. Chemical composition (in \%) of essential oils of Dunaliella salina

\begin{tabular}{|c|c|c|}
\hline Compounds & $r t$ & D. salina \\
\hline Ethane, 1-Chloro-1-Fluoro-(Cas) 1-Chloro-1-Fluoroethane & 2.417 & 0.16 \\
\hline (S)-Isopropyl Lactate & 3.500 & 0.24 \\
\hline N-Methyl-N-(Methyl-D3)Aminoheptane & 3.554 & 1.62 \\
\hline Acetic Acid, [(Phenylmethoxy)Imino]-, Trimethylsilyl Ester & 3.747 & 3.08 \\
\hline Acetic Acid, Hydroxy-, Methyl Ester (Cas) Methyl Glycolate & 3.875 & 0.41 \\
\hline Oxiranemethanol (Cas) Glycidol & 3.924 & 1.57 \\
\hline Propanoic Acid, 2-Hydroxy-, Methyl Ester (Cas) Methyl Lactate & 3.958 & 0.79 \\
\hline 1-Tetradecene & 10.018 & 0.18 \\
\hline Phenol, 2,4-Bis(1,1-Dimethylethyl)- (Cas) 2,4-Di-Tert-Butylphenol & 10.308 & 0.24 \\
\hline Phenol, 2,4-Bis(1,1-Dimethylethyl)- (Cas) 2,4-Di-Tert-Butylphenol & 11.125 & 0.92 \\
\hline Di(Butoxyethyl)Adipate & 11.427 & 0.47 \\
\hline 1-Hexadecene (Cas) Cetene & 11.711 & 0.20 \\
\hline Propanoic Acid, 2-Methyl-,1-(1,1-Dimethylethyl)-2-Methyl-1,3-Propanediyl Ester (Cas) & 11.845 & 0.17 \\
\hline Tetradecanoic Acid, Methyl Ester (Cas) Methyl Myristate & 12.739 & 0.42 \\
\hline Heneicosanoic Acid, Methyl Ester & 13.208 & 0.17 \\
\hline 9-Octadecenoic Acid (Z)- (Cas) Oleic Acid & 13.566 & 0.95 \\
\hline Z,E-3,13-Octadecadien-1-Ol & 13.875 & 0.24 \\
\hline Methyl Eicosa-5,8,11,14,17-Pentaenoate & 13.941 & 1.79 \\
\hline 3,6-Octadecadienoic Acid, Methyl Ester (Cas) Methyl 3,6-Octadecadienoate & 14.029 & 0.61 \\
\hline Hexadecanoic Acid, Methyl Ester (Cas) Methyl Palmitate & 14.168 & 24.82 \\
\hline Pentadecanoic Acid & 14.409 & 3.60 \\
\hline Heneicosanoic Acid, Methyl Ester & 14.861 & 0.24 \\
\hline 10-Heptadecen-8-Ynoic Acid, Methyl Ester, (E)- & 15.325 & 0.71 \\
\hline 9,12-Octadecadienoic Acid (Z,Z)- & 15.433 & 1.62 \\
\hline 9,12,15-Octadecatrienoic Acid, Ethyl Ester, (Z,Z,Z)- & 15.502 & 7.39 \\
\hline Phytol & 15.585 & 1.81 \\
\hline Octadecanoic Acid, Methyl Ester & 15.654 & 27.43 \\
\hline Cyclopentane, 1-Pentyl-2-Propyl- (Cas) & 15.717 & 0.26 \\
\hline Octadecanoic Acid & 15.964 & 5.03 \\
\hline Octadecanamide & 16.201 & 0.56 \\
\hline 9-Hexadecenoic Acid, Methyl Ester, (Z)- (Cas) Methyl Palmitoleate & 16.441 & 0.86 \\
\hline Hexadecanoic Acid, 2-Hydroxy-1,3-Propanediyl Ester(Cas)Glycerol1,3-Dihexadecanoate & 17.115 & 0.75 \\
\hline Eicosanoic Acid, Methyl Ester (Cas) Arachidic Acid Methyl Ester & 17.310 & 0.51 \\
\hline 9-Octadecenamide, $(\mathrm{Z})$ - (Cas) Oleoamıde & 17.679 & 0.70 \\
\hline Tetradecanamide & 17.827 & 0.72 \\
\hline 1,3,5-Trisilacyclohexane (Cas) Cyclocarbosilane & 18.405 & 0.55 \\
\hline Hexanoic Acid, Heptadecyl Ester & 18.499 & 1.18 \\
\hline Octadecanoic Acid,2-Hydroxy-1,3-Propanediyl Ester(Cas)Glycerol-1,3-DiOctadecanoate & 18.569 & 0.59 \\
\hline Hexadecanoic Acid, 2-Hydroxy-1-(Hydroxymethyl)Ethyl Ester & 18.655 & 2.11 \\
\hline Docosanoic Acid, Methyl Ester & 18.708 & 0.40 \\
\hline Octadecanoic Acid, 2,3-Dihydroxypropyl Ester & 19.008 & 0.27 \\
\hline Tetracontane & 19.138 & 0.50 \\
\hline 18.Alpha.-Olean-3.Beta.-Ol, Acetate & 19.243 & 0.23 \\
\hline 1,3,5-Trisilacyclohexane (Cas) Cyclocarbosilane & 19.740 & 0.15 \\
\hline Nonacosane & 19.820 & 0.87 \\
\hline Hexadecanoic Acid, 2-Hydroxy-1-(Hydroxymethyl) Ethyl Ester & 20.058 & 0.40 \\
\hline Tetracontane & 20.534 & 0.50 \\
\hline 2,6,10,14,18,22-Tetracosahexaene, 2,6,10,15,19,23-Hexamethyl-, (All-E)- & 20.889 & 0.37 \\
\hline Tetracontane & 21.327 & 0.34 \\
\hline Dotriacontane (Cas) N-Dotriacontane & 22.229 & 0.28 \\
\hline
\end{tabular}


or antagonistic relationship between palmitic acid and steraic acid should be investigated. Palmitic acid/steraic acid ratios of Dunaliella salina might be at optimal level for neuroblastoma cells. Ethyl esters, which are also defined as ethanolic esters, and pentadecanoic acid, which is a saturated fatty acid, have been found in algae extracts of Hypnea flagelliformis. The antimicrobial effects of Hypnea flagelliformis have been similarly reported previously (Jassbi et al. 2013). Also anticancer effects of pentadecanoic acid were shown by various studies (Budczies et al. 2012; Zeng et al. 2012).

All of these major fatty acids found in algae extracts have not been previously reported for Dunaliella salina green alga. Results suggest that Dunaliella salina extract clearly shows selective cytotoxic potential. One of the advantages of our findings is that effects of the extract requires no isolation step for its individual chemical substituents. On the other hand, proliferative effects of the extract were shown against ECV304 cells. Only the highest concentration of the extract showed cytotoxic effect against SH-SY5Y cells. This cytotoxic activity might be due to the high concentrations of octadecanoic acid, hexadecanoic acid and other fatty acid compounds. Our results show that Dunaliella salina possessed anticancer potential for malignant neuroblastoma cells. In vivo studies should be considered to explain cytotoxicity mechanisms and anti-tumoral effects of Dunaliella salina extract. Detailed studies are in progress for the determination of possible underneath mechanisms of cytotoxic effects of chemical substituents identified in this study and biological potentials of Dunaliella salina extract.

Acknowledgements. We thank Assist. Prof. Dr. Kenan Ates from Istanbul University for SH-SY5Y human neuroblastoma cells. This study was supported by the Scientific and Technological Research Council of Turkey (TUBITAK) 3501 (Project No: 113S251).

Conflict of interest: Authors have no conflict of interest.

\section{References}

Atasever B., Ülküseven B., Bal-Demirci T., Erdem-Kuruca S., Solakoğlu Z. (2010): Cytotoxic activities of new iron(III) and nickel(II) chelates of some S-methyl-thiosemicarbazones on K562 and ECV304 cells. Invest. New Drugs 28, 421-432 http://dx.doi.org/10.1007/s10637-009-9272-2

Bechelli J., Coppage M., Rosell K., Liesveld J. (2011): Cytotoxicity of algae extracts on normal and malignant cells. Leuk. Res. Treatment 2011, 373519 http://dx.doi.org/10.4061/2011/373519

Budczies J., Denkert C., Müller B. M., Brockmöller S. F., Klauschen F., Györffy B., Dietel M., Richter-Ehrenstein C., Marten U., Salek R. M., Griffin J. L., Hilvo M., Orešič M., Wohlgemuth G., Fiehn O. (2012): Remodeling of central metabolism in invasive breast cancer compared to normal breast tissue - a GC-TOFMS based metabolomics study. BMC Genomics 13, 334 http://dx.doi.org/10.1186/1471-2164-13-334
Cheng Y., Zhang L., Sun W., Tang J., Lv Z., Xu Z., Yu H. (2014): Protective effects of a wheat germ peptide (RVF) against $\mathrm{H} 2 \mathrm{O} 2$-induced oxidative stress in human neuroblastoma cells. Biotechnol. Lett. 36, 1615-1622

http://dx.doi.org/10.1007/s10529-014-1521-6

Fattore E., Fanelli R. (2013): Palm oil and palmitic acid: a review on cardiovascular effects and carcinogenicity. Int. J. Food Sci. Nutr. 64, 648-659 http://dx.doi.org/10.3109/09637486.2013.768213

Fu W., Paglia G., Magnúsdóttir M., Steinarsdóttir E. A., Gudmundsson S., Palsson B. O., Andrésson O. S., Brynjólfsson S. (2014): Effects of abiotic stressors on lutein production in the green microalga Dunaliella salina. Microb. Cell Fact. 13, 3 http://dx.doi.org/10.1186/1475-2859-13-3

Gamal-Eldeen A. M., Ahmed E. F., Abo-Zeid M. A. (2009): In vitro cancer chemopreventive properties of polysaccharide extract from the brown alga, Sargassum latifolium. Food Chem. Toxicol. 47, 1378-1384 http://dx.doi.org/10.1016/j.fct.2009.03.016

Gonzalez-Nunez V., Noriega-Prieto J. A., Rodríguez R. E. (2014): Morphine modulates cell proliferation through mir133b \&mir128 in the neuroblastoma SH-SY5Y cell line. Biochim. Biophys. Acta 1842, 566-572 http://dx.doi.org/10.1016/j.bbadis.2014.01.003

Gu L., Smith S., Li C., Hickey R. J., Stark J. M., Fields G. B., Lang W. H., Sandoval J. A., Malkas L. H. (2014): A PCNA-derived cell permeable peptide selectively inhibits neuroblastoma cell growth. PLoS ONE 9, e94773 http://dx.doi.org/10.1371/journal.pone.0094773

Hagen R. M., Rhodes A., Ladomery M. R. (2013): Conjugated linoleate reduces prostate cancer viability whereas the effects of oleate and stearate are cell line-dependent. Anticancer Res. 33, 4395-4400

Ishikawa C., Tafuku S., Kadekaru T., Sawada S., Tomita M., Okudaira T., Nakazato T., Toda T., Uchihara J. N., Taira N. et al. (2008): Anti-adult T-cell leukemia effect6s of brown algae fucoxanthin and its deacetylated product, fucoxanthinol. Int. J. Cancer 123, 2702-2712 http://dx.doi.org/10.1002/ijc.23860

Jassbi A. R., Mohabati M., Eslami S., Sohrabipour J., Miri R. (2013): Biological activity and chemical constituents of red and brown algae from the Persian gulf. Iran J. Pharm. Res. 12, 339-348

Khan A. A., Alanazi A. M., Jabeen M., Chauhan A., Abdelhameed A. S. (2013): Design, synthesis and in vitro anticancer evaluation of a stearic acid-based ester conjugate. Anticancer. Res. 33, 2517-2524

Kotake-Nara E., Terasaki M., Nagao A. (2005): Characterization of apoptosis induced by fucoxanthin in human promyelocytic leukemia cells. Biosci. Biotechnol. Biochem. 69, 224-227 http://dx.doi.org/10.1271/bbb.69.224

Li D., Liu Q., Jia D., Dou D., Wang X., Kang T. (2014): Protective effect of arctigenin against MPP+ and MPTP-induced neurotoxicity. Planta Med. 80, 48-55 http://dx.doi.org/10.1055/s-0033-1360171

Li Y., Han D., Sommerfeld M., Hu Q. (2011): Photosynthetic carbon partitioning and lipid production in the oleaginous microalga Pseudochlorococcum sp. (Chlorophyceae) under nitrogenlimited conditions. Bioresour Technol. 102, 123-129 
http://dx.doi.org/10.1016/j.biortech.2010.06.036

Machana S., Weerapreeyakul N., Barusrux S., Thumanu K., Tanthanuch W. (2012): Synergistic anticancer effect of the extracts from Polyalthia evecta caused apoptosis in human hepatoma (HepG2) cells. Asian Pacific J. Tropical Biomed. 589-596

Miadoková E., Svidová S., Vlcková V., Dúhová V., Prazmáriová E., Tothová K., Nad'ová S., Kogan G., Rauko P. (2005): The role of natural biopolymers in genotoxicity of mutagens/carcinogens elimination. Biomed. Pap. Med. Fac. Univ. Palacky Olomouc Czech Repub. 149, 493-496 http://dx.doi.org/10.5507/bp.2005.088

Miadokova E., Chalupa I., Vlckova V., Sevcovicova A., Nadova S., Kopaskova M., Hercegova A., Gasperova P., Alfoldiova L., Komjatiova M., Csanyiova Z., Galova E., Cellarova E., Vlcek D. (2010): Genotoxicity and antigenotoxicity evaluation of nonphotoactivated hypericin. Phytother. Res. 24, 90-95 http://dx.doi.org/10.1002/ptr.2901

Paul N. A., de Nys R., Steinberg P. D. (2006): Chemical defence against bacteria in the red alga Asparagopsis armata: linking structure with function. Mar. Ecol. Prog. Ser. 306, 87-101 http://dx.doi.org/10.3354/meps306087

Pereira D. M., Correia-da-Silva G., Valentão P., Teixeira N., Andrade P. B. (2013): Palmitic acid and ergosta-7,22-dien-3-ol contribute to the apoptotic effect and cell cycle arrest of an extract from Marthasterias glacialis L. in neuroblastoma cells. Mar Drugs. 12, 54-68 http://dx.doi.org/10.3390/md12010054

Pirildar S., Sütlüpınar N., Atasever B., Erdem-Kuruca S., Papouskova B., Šimánek V. (2010): Chemical Constituents of the Different Parts of Colchicum baytopiorum (Liliaceae) and Their Cytotoxic Activities on K562 and HL60 cell-lines. Pharm. Biol. 48, 32-39 http://dx.doi.org/10.3109/13880200903029373

Raja R., Hemaiswarya S., Balasubramanyam D., Rengasamy R. (2007): Protective effect of Dunaliella salina (Volvocales, Chlorophyta) against experimentally induced fibrosarcoma on wistar rats. Microbiol. Res. 162, 177-184 http://dx.doi.org/10.1016/j.micres.2006.03.009
Rastogi R. P., Incharoensakdi A. (2013): UV radiation-induced accumulation of photoprotective compounds in the green alga Tetraspora sp. CU2551. Plant Physiol. Biochem. 70, 7-13 http://dx.doi.org/10.1016/j.plaphy.2013.04.021

Subbaramaiah K., Sue E., Bhardwaj P., Du B., Hudis C. A., Giri D., Kopelovich L., Zhou X. K., Dannenberg A. J. (2013): Dietary polyphenols suppress elevated levels of proinflammatory mediators and aromatase in the mammary gland of obese mice. Cancer Prev. Res. (Phila) 6, 886-897 http://dx.doi.org/10.1158/1940-6207.CAPR-13-0140

Suda K., Rothen-Rutishauser B., Günthert M., Wunderli-Allenspach H. (2001): Phenotypic characterization of human umbilical vein endothelial (ECV304) and urinarycarcinoma (T24) cells: endothelial versus epithelial features. In Vitro Cell Dev. Biol. Anim. 37, 505-514

http://dx.doi.org/10.1290/1071-2690(2001)037<0505:PCOH$\mathrm{UV}>2.0 . \mathrm{CO} ; 2$

Svobodova H., Jost P., Stetina R. (2012): Cytotoxicity and genotoxicity evaluation of antidote HI-6 tested on eight cell lines of human and rodent origin. Gen. Physiol. Biophys. 31, 77-84 http://dx.doi.org/10.4149/gpb_2012_010

Zandi K., Tajbakhsh S., Nabipour I., Rastian Z., Yousefi F., Sharafian S., Sartavi K. (2010): In vitro antitumor activity of Gracilaria corticata (a red alga) against Jurkat and molt- 4 human cancer cell lines. African J. Biotechnol. 9, 6787-6790

Zemke P. E., Sommerfeld M. R., Hu Q. (2013): Assessment of key biological and engineering design parameters for production of Chlorella zofingiensis (Chlorophyceae) in outdoor photobioreactors. Appl. Microbiol. Biotechnol. 97, 5645-5655 http://dx.doi.org/10.1007/s00253-013-4919-5

Zeng X., Wang Y., Qiu Q., Jiang C., Jing Y., Qiu G., He X. (2012): Bioactive phenolics from the fruits of Livistona chinensis. Fitoterapia 83, 104-109 http://dx.doi.org/10.1016/j.fitote.2011.09.020

Received: August 21, 2014

Final version accepted: October 13, 2014

First published online: March 2, 2015 